\title{
Effect of SstI Polymorphism of the Apolipoprotein CIII Gene and Environmental Factors on Risks of Hypertriglyceridemia in Taiwan Aborigines
}

\author{
Meng-Chuan Huang, PhD*,**; Tsu-Nai Wang, PhD ; Yi-Ling Liu, MS*; \\ Te-Hsiung Pa, MS, MD ${ }^{*}$; Hung-Ping Tu, MS*; Yi-Chia Huang, $\mathrm{PhD}^{*}$; \\ Wen-Tsan Chang, MS, MD*; Ying-Chin Ko, MD, PhD*,\&
}

\begin{abstract}
Background Hypertriglyceridemia (HTG) is a heterogeneous metabolic disorder. The aim of this study was to examine associations among genetic polymorphisms, SstI polymorphism of apolipoprotein CIII (ApoCIII) and Hind III polymorphism of lipoprotein lipase (LPL), environmental factors and risks of HTG.

Methods and Results Two hundred and forty-nine southern Taiwanese aborigines were recruited for a crosssectional study, which included 90 subjects with triglyceride (TG) $>150 \mathrm{mg} / \mathrm{dl}$ (HTG) and 159 with TG $\leq 150 \mathrm{mg} / \mathrm{dl}$ (NTG). The frequencies of SstI major allele (S1) and minor allele (S2) of ApoCIII were $66.1 \%$ and $33.9 \%$ in HTG and $73.6 \%$ and $26.4 \%$ in NTG $(\mathrm{p}<0.1)$. In female subjects, the frequencies of the S2 allele was significantly higher in HTG $(0.38)$ than NTG $(0.27)(\mathrm{p}<0.04)$. The frequencies of the LPL HindIII major allele $(\mathrm{H}+)$ and minor allele $(\mathrm{H}-)$ were similar between $\mathrm{HTG}(\mathrm{H}+84.3 \% ; \mathrm{H}-15.7 \%)$ and $\mathrm{NTG}(\mathrm{H}+78.9 \% ; \mathrm{H}-21.1 \%)$. In a multivariate adjusted logistic model, education $\leq 6$ year (odds ratio $(\mathrm{OR})=3.71,95 \%$ confidence interval $(\mathrm{CI})$ : 1.24-8.13), Amis tribe (OR=3.08, 95\% CI: 1.41-6.77), body mass index (BMI) $\geq 25$ (OR=2.22, 95\% CI: $1.18-$ 4.16), starchy food consumption $\geq 3$ times/week $(\mathrm{OR}=1.89$, 95\% CI: $1.00-3.59)$ and ApoCIII S2S2 genotype $(\mathrm{OR}=3.35,95 \% \mathrm{CI}: 1.10-10.19)$ were independently $(\mathrm{p}<0.05)$ associated with HTG risks. Among ApoCIII S1S1, S1S2 and S2S2 genotypes, ApoCIII and TG concentrations increased $(p<0.01)$ in a dose-responsive manner.

Conclusions The ApoCIII S2 variant and environmental factors, including education, tribal background, BMI and starchy food intake, modulate the risks of HTG in aboriginal Taiwanese. Interaction between genetic and environmental factors warrants further investigation. (Circ J 2006; 70: 1030-1036)
\end{abstract}

Key Words: Apolipoprotein CIII SstI; HindIII; Hypertriglyceridemia; Lipoprotein lipase polymorphism; Taiwan aborigines

M ounting evidence supports an independent association between hypertriglyceridemia (HTG) and coronary artery disease $(\mathrm{CAD})^{1-3}$ a relationship that likely stems from the atherogenicity of some species of triglyceride (TG)-rich lipoproteins, particularly small very (V)-low-density lipoprotein (LDL) and intermediate-density lipoprotein particles4. Based on the 1993-1996 National Nutrition Survey in Taiwan, 5 the prevalence of HTG in aboriginal adults (age $>19$ years) was the highest compared with other non-aboriginal regions investigated. In 2004, the 5 th and 6th leading causes of death in aborigines were cerebrovascular and heart diseases, the respective death rates being higher than those of non-aborigines6 During the

(Received July 28, 2005; revised manuscript received May 11, 2006; accepted May 23, 2006)

*Department of Public Health, School of Medicine, Kaohsiung Medical University, **Department of Nutrition, Kaohsiung Medical University Chung-Ho Memorial Hospital, 'School of Public Health, Kaohsiung Medical University, Kaohsiung, HTaimali Township Public Health Center, Tai-Tung, \$School of Nutrition, Chung Shan Medical University, Taichung, \#Department of Surgery, Kaohsiung Medical University Chung-Ho Memorial Hospital and \$Division of Environmental Health and Occupational Medicine, National Health Research Institutes, Kaohsiung, Taiwan

Mailing address: Ying-Chin Ko, MD, PhD, Professor/Principle Investigator, Division of Environmental Health and Occupational Medicine, National Health Research Institute, 100 Shih-Chuan 1st Road, Kaohsiung 807, Taiwan. E-mail: ycko@nhri.org.tw period of 1981-1990, it was reported that standardized mortality rates for heart diseases and stroke in aborigines were significantly higher than those for non-aborigines in Taiwan? A similar trend was also found during 1991-2000. Significantly higher standardized mortality rates for ischemic heart disease $(1.13,95 \%$ confidence interval (CI): 1.02-1.26) in male aborigines and cerebrovascular accident in male (1.98, 95\% CI: $1.88-2.08)$ and female (1.64, 95\% CI: $1.54-1.76)$ aborigines were observed compared with non-aborigines in Taiwan?

The ApoAI/CIII/AIV gene complex on chromosome $11 \mathrm{q}^{9}$ is a strong candidate for the susceptibility region for common HTG. Apolipoprotein CIII (ApoCIII) is a major apolipoprotein of VLDL and chylomicrons, inhibiting lipoprotein lipase (LPL) of the TG carried by these particles! ${ }^{10}$ Overexpression of human ApoCIII causes severe HTG in transgenic mice. A transversion from $\mathrm{C}$ to $\mathrm{G}$ in the 3 ' untranslated region (3'UTR) of exon 4 in ApoCIII results in SstI polymorphism.11 Associations between the less common S2 allele of SstI polymorphism and elevated TG concentrations have been reported in different ethnic groups, including Japanese ${ }^{12}$ Asian Indians ${ }^{13}$ Arabs ${ }^{14}$ Caucasians ${ }^{15}$ and Chinese 16 However, some other studies have shown contradictory results! 17,18

LPL-catalyzed hydrolysis of TG constitutes the ratelimiting step in the removal from the circulation of TG-rich lipoproteins, such as VLDL and chylomicrons, for uptake 
of free fatty acids and glycerol by peripheral tissues for oxidation or storage. The gene for human LPL has recently been cloned, localized to chromosome 8 , and found to code for a protein of $65,000 \mathrm{kDa}{ }^{19} \mathrm{~A}$ common sequence variant, the intron 8 HindIII polymorphism, is reportedly associated with subtle alterations in plasma lipids or atherosclerosis risk. Studies of HindIII polymorphisms have reported associations with HTG ${ }^{16,20}$ levels of cholesterol (C), and highdensity lipoprotein (HDL) ${ }^{21}$ and coronary heart diseases? 2

Approximately $86 \%$ of Taiwanese are descended from Han Chinese whose ancestors migrated 400 years ago from Fukkien and Canton provinces ${ }^{23}$ Taiwanese aboriginals constitute approximately $2 \%$ of the population, rarely mix with Han Chinese and reside in isolated mountainous areas with their own language, customs and social organizations. Genetically, they are markedly different from Han Chinese 24 HTG is a complicated metabolic disease, and both environmental and genetic factors exercise profound influence on determination of blood lipid levels. Considering the high prevalence of HTG, as one of the underlining risk factors in the progression of $\mathrm{CAD}$, in the aboriginal population of Taiwan, the current study aimed to investigate (1) the association of ApoCIII SstI and LPL HindIII polymorphisms with a phenotype of elevated TG in a cross-sectional study, and (2) the effect of these genetic variations with the simultaneous presence of environmental factors on risks of HTG.

\section{Methods}

\section{Subjects}

From July 2002 to June 2003, community health examinations of a total of 475 subjects were performed in aboriginal villages, Taimali (Tai-Tung) and Machia (Ping-Tung), of southern Taiwan. Parental origin determined a participant's aboriginal tribal classification and only subjects whose parents were from the same tribe were analyzed. After excluding non-aborigines and mixed aborigines, there was a total of 249 unrelated subjects. Of these, 90 had plasma TG $>150 \mathrm{mg} / \mathrm{dl}$ (HTG) and 159 had TG levels $\leq 150 \mathrm{mg} / \mathrm{dl}$ (NTG), based on the definition of elevated TG set by the National Cholesterol Education Program? All subjects gave informed consent for blood samples, anthropometric measurements and questionnaire interviews, and the protocol was approved by the Human Ethical Committee of Kaohsiung Medical University.

\section{Data Collection}

Weight and height were measured. Information regarding demographic characters, age and parents' tribal background, use of alcohol, betel nut and cigarettes, and food frequency was obtained by a structured questionnaire completed by each subject.

\section{Blood Collection}

After fasting, blood was drawn and plasma/white blood cells were separated within $3 \mathrm{~h}$. An aliquot of plasma was stored at $-80^{\circ} \mathrm{C}$ until ApoCIII analysis using TBA-40FR (Toshiba, Tokyo, Japan) auto-analyzer, and another aliquot of fresh blood was stored at $4{ }^{\circ} \mathrm{C}$ for routine blood tests, which were performed within 2 days of collecting blood. These measurements included fasting plasma glucose, TG, $\mathrm{C}$, and uric acid using an auto-analyzer (Biotechnica, Hitachi, Tokyo), and HDL-C and LDL-C using a TBA40FR analyzer (Toshiba, Tokyo, Japan). DNA was extracted using a GFXTM Genomic Blood DNA purification
Table 1 Demographic and Clinical Profile of Taiwan Aborigines With HTG

\begin{tabular}{lccc}
\hline \hline & $\begin{array}{c}H T G \\
(n=90)\end{array}$ & $\begin{array}{c}N T G \\
(n=159)\end{array}$ & $p$ value \\
\hline Age (years) & $57.5 \pm 11.7$ & $55.7 \pm 15.3$ & 0.32 \\
Body mass index $\left(\mathrm{kg} / \mathrm{m}^{2}\right)$ & $27.8 \pm 5.5$ & $26.5 \pm 5.7$ & 0.09 \\
Fasting plasma glucose $(\mathrm{mg} / \mathrm{dl})$ & $134.3 \pm 97.3$ & $106.6 \pm 42.7$ & $<0.001$ \\
Triglyceride $(\mathrm{mg} / \mathrm{dl})$ & $263.8 \pm 167.9$ & $87.7 \pm 32.0$ & $<0.001$ \\
Log-triglyceride $(\mathrm{mg} / \mathrm{dl})$ & $2.4 \pm 0.2$ & $1.9 \pm 0.2$ & $<0.001$ \\
Total cholesterol $(\mathrm{mg} / \mathrm{dl})$ & $194.2 \pm 43.3$ & $165.5 \pm 35.9$ & $<0.001$ \\
LDL-cholesterol $(\mathrm{mg} / \mathrm{dl})$ & $103.9 \pm 41.5$ & $97.3 \pm 35.4$ & 0.19 \\
HDL-cholesterol $(\mathrm{mg} / \mathrm{dl})$ & $42.3 \pm 8.9$ & $48.9 \pm 12.3$ & $<0.001$ \\
Uric acid $(\mathrm{mg} / \mathrm{dl})$ & $7.0 \pm 1.9$ & $6.5 \pm 1.7$ & 0.02 \\
Apolipoprotein $\mathrm{CIII}(\mathrm{mg} / \mathrm{dl})$ & $11.6 \pm 4.9$ & $7.2 \pm 2.9$ & $<0.001$ \\
\hline
\end{tabular}

Data are mean $\pm S D ; p<0.05$ is considered significantly different.

$H T G$, hypertriglyceridemia, subjects with serum triglycerides $>150 \mathrm{mg} / \mathrm{dl}$; $N T G$, subjects with serum triglycerides $\leq 150 \mathrm{mg} / \mathrm{dl} ; \mathrm{LDL}$, low-density lipoprotein; $H D L$, high-density lipoprotein; $S D$, standard deviation.

kit (Amersham Pharmacia Biotech, NJ, USA) and stored at $-20^{\circ} \mathrm{C}$ until genotyping.

\section{Genotyping}

Polymerase Chain Reaction (PCR) Amplification DNA samples were subjected to amplification by PCR in an automatic thermal cycler. One set of primers was from the DNA sequences of ApoCIII with sense primer of 5'-GGCTGGG TGACCGATGGCTTC-3' and anti-sense primer of 5'-GGG AGGCCAGCATGCCTGGAG-3'. The other set of primers was derived from sequences between exons 8 and 9 in LPL to amplify the sequence around a HindIII restriction site in intron 8 (the forward primer was 5'-TTTAGGCCTGAAG TTTCCAC-3' and the reverse primer was 5'-CTCCCTAG AACAGAAGATC-3'). The 50 1 reaction mixture contained $1 \times$ PCR buffer $\left(2.0 \mathrm{mmol} \mathrm{MgCl}_{2}\right)$, dNTPs at $2.5 \mathrm{mmol} / \mathrm{L}, 2.0 \mu \mathrm{g} \mu \mathrm{l}$ each primer, $2 \mu \mathrm{g}$ genomic DNA and 0.6 units of Taq DNA polymerase. Amplification of the SstI site of ApoCIII was subject to 35 temperature cycles, which consisted of denaturing at $95^{\circ} \mathrm{C}$ for $5 \mathrm{~min}$, annealing at $58^{\circ} \mathrm{C}$ for $1 \mathrm{~min}$ and extension at $72^{\circ} \mathrm{C}$ for $5 \mathrm{~min}$. Amplification of the HindIII site of LPL was performed for 33 thermal cycles consisting of denaturing at $94^{\circ} \mathrm{C}$ for $5 \mathrm{~min}$, annealing at $60^{\circ} \mathrm{C}$ for $2 \mathrm{~min}$ and extension at $72^{\circ} \mathrm{C}$ for $2 \mathrm{~min}$.

For detection of restriction fragment length polymorphisms in PCR-amplified DNA, amplified products were digested with SstI or HindIII, and the resulting fragments were separated on 2\% agarose gels. After electrophoresis, the gel was treated with ethidium bromide for $20 \mathrm{~min}$ and DNA fragments were visualized by UV illumination. Upon digestion with SstI, the presence of the restriction site (S2 allele) resulted in fragments of 322 and $230 \mathrm{bp}$ and $552 \mathrm{bp}$ for the uncut S1 allele. For LPL, the presence of the HindIII site yielded fragments of $600 \mathrm{bp}$ and $700 \mathrm{bp}(\mathrm{H}+$ allele $)$ and the uncut $\mathrm{H}$ - allele had 1,300 bp.

\section{Statistical Analysis}

$\mathrm{T}$ test was used to analyze differences in continuous variables, and the chi-square test was used to analyze distribution of categorical variables (if $\mathrm{n}<5$, Fisher exact test was used). Odds ratio (OR) and $95 \% \mathrm{CI}$ were used to estimate risks of HTG associated with environmental factors obtained from the questionnaire or serum blood chemistry. Those variables with significant OR in the univariate analysis were further examined by multivariate logistic regres- 
Table 2 Genotype Distribution and Allele Frequencies for the ApoCIII-SstI Polymorphism in HTG and NTG Subjects

\begin{tabular}{|c|c|c|c|c|c|}
\hline \multirow{2}{*}{ Subjects } & \multicolumn{3}{|c|}{ Genotype } & \multicolumn{2}{|c|}{ Allele frequency } \\
\hline & S1S1 & $S 1 S 2$ & $S 2 S 2$ & S1 & $S 2$ \\
\hline \multicolumn{6}{|l|}{ Total } \\
\hline$H T G(n=90)$ & $42(46.7)$ & 35 (38.9) & $13(14.4)$ & $119(66.1)$ & $61(33.9)$ \\
\hline$N T G(n=159)$ & $85(53.5)$ & $64(40.2)$ & $10(6.3)$ & $234(73.6)$ & 84 (26.4) \\
\hline p value & & 0.096 & & 0.078 & \\
\hline \multicolumn{6}{|l|}{ Males } \\
\hline$H T G(n=33)$ & $17(51.5)$ & $15(44.5)$ & $1(3.0)$ & $49(74.2)$ & $17(25.8)$ \\
\hline$N T G(n=44)$ & $26(59.1)$ & $15(34.1)$ & $3(6.8)$ & $67(76.1)$ & 21 (23.9) \\
\hline$p$ value & & 0.51 & & 0.85 & \\
\hline \multicolumn{6}{|l|}{ Females } \\
\hline$H T G(n=57)$ & 25 (43.9) & $20(35.1)$ & $12(21.0)$ & 70 (61.4) & 44 (38.6) \\
\hline$N T G(n=115)$ & $59(51.3)$ & $49(42.6)$ & $7(6.1)$ & $167(72.6)$ & $63(27.4)$ \\
\hline$p$ value & & 0.013 & & 0.036 & \\
\hline
\end{tabular}

Data are number (\%), chi-square was used to test the differences. If $n<5$, Fisher exact test was used. $p<0.05$ is considered statistically significant.

ApoCIII, apolipoprotein III. Other abbreviations see in Table 1.

Table 3 Genotype Distribution and Allele Frequencies for the LPL-HindIII Polymorphism in HTG and NTG Subjects

\begin{tabular}{|c|c|c|c|c|c|}
\hline & \multicolumn{3}{|c|}{ Genotype distribution } & \multicolumn{2}{|c|}{ Allele frequency } \\
\hline & $H-H-$ & $H-H+$ & $H+H+$ & $H-$ & $H+$ \\
\hline \multicolumn{6}{|l|}{ Total } \\
\hline$H T G(n=89)$ & $3(3.4)$ & $22(24.7)$ & 64 (71.9) & $28(15.7)$ & $150(84.3)$ \\
\hline$N T G(n=159) *$ & $3(1.9)$ & $61(38.4)$ & $95(59.7)$ & $67(21.1)$ & $251(78.9)$ \\
\hline$p$ value & & 0.082 & & 0.147 & \\
\hline \multicolumn{6}{|l|}{ Males } \\
\hline$H T G(n=33)$ & $1(3.0)$ & $6(18.2)$ & $26(78.8)$ & $8(12.1)$ & $58(87.9)$ \\
\hline$N T G(n=44)$ & $0(0.0)$ & $21(47.7)$ & $23(52.3)$ & $21(23.9)$ & $67(76.1)$ \\
\hline$p$ value & & 0.017 & & 0.065 & \\
\hline \multicolumn{6}{|l|}{ Females } \\
\hline$H T G(n=57)$ & $2(3.6)$ & $16(28.6)$ & 38 (67.9) & $20(17.9)$ & $92(82.1)$ \\
\hline$N T G(n=115)$ & $3(2.6)$ & $40(34.8)$ & $72(62.6)$ & $46(20.0)$ & $184(80.0)$ \\
\hline$p$ value & & 0.696 & & 0.664 & \\
\hline
\end{tabular}

Data are number (\%), chi-square was used to test the differences, if $n<5$, Fisher exact test was used. $p<0.05$ is considered statistically significant.

LPL, lipoprotein lipase. Other abbreviations see in Table 1.

*One sample missing because of failure of polymerase chain reaction.

sion model to obtain adjusted OR and adjusted $95 \% \mathrm{CI}$. Differences were considered statistically significant when $\mathrm{p}<0.05$ or when the $95 \% \mathrm{CI}$ range was not included in the unity. SAS 8.0 Version (Cary, NC, USA) was used to complete the statistical analyses.

\section{Results}

The clinical and biochemical features of the study subjects are listed in Table 1. There were no differences in sex distribution and mean age between the HTG and NTG groups. Concentrations of fasting plasma glucose, C, TG, $\log$-TG, ApoCIII and uric acid levels were significantly $(p<0.05)$ higher in the HTG group than the NTG group and HDL-C was significantly lower in HTG subjects $(\mathrm{p}<0.05)$. No differences in body mass index (BMI) and LDL-C were observed between the 2 groups.

The genotype and allelic distributions of the ApoCIII-SstI and LPL-HindIII polymorphisms in the study population and their distribution in the 2 genders are shown in Tables 2 and 3. Overall, the allelic frequencies of the $\mathrm{S} 2$ allele of the ApoCIII-SstI polymorphisms were $0.34(\mathrm{n}=61)$ in the HTG group and $0.26(\mathrm{n}=84)$ in the NTG group $(\mathrm{p}=0.078)$, reaching marginal significance between the 2 groups. As separately analyzed in the female group, significant differences in
S2 distribution was observed between HTG (S2 frequency: $0.39, \mathrm{n}=44$ ) and the NTG (S2 frequency: 0.27, $\mathrm{n}=63$ ). There were also significant differences between the HTG and NTG groups in the distribution of S1S1, S1S2 and $\mathrm{S} 2 \mathrm{~S} 2$ genotypes in the female subjects $(\mathrm{p}<0.05)$. The frequencies of S1S1, S1S2 and S2S2 were $43.9 \%(n=25)$, $35.1 \%(\mathrm{n}=20)$ and $21.0 \%(\mathrm{n}=12)$ in the HTG group and $51.3 \%(\mathrm{n}=59), 42.6 \%(\mathrm{n}=49)$ and $6.1 \%(\mathrm{n}=7)$, respectively, in the NTG $(\mathrm{p}=0.013)$. The genotyping of LPL-HindIII of 1 case could not be determined and thus was excluded from the analysis. The allelic frequencies of the $\mathrm{H}+$ allele of the LPL-HindIII polymorphisms were similar between the HTG and NTG groups. Overall, the frequency of the H+ allele was $0.84(n=150)$ and $0.79(n=251)$ in the HTG and NTG groups respectively $(\mathrm{p}=0.147)$. The distribution of the $\mathrm{H}-/ \mathrm{H}-, \mathrm{H}-/ \mathrm{H}+$ and $\mathrm{H}+/ \mathrm{H}+$ genotypes was $3.4 \%(\mathrm{n}=3)$, $24.7 \%(n=22)$ and $71.9 \%(n=64)$ in the HTG group and $1.9 \%(n=3), 38.4 \%(n=61)$ and $59.7 \%(n=95)$, respectively, in the NTG group ( $\mathrm{p}=0.082)$. No differences in the frequencies of the $\mathrm{H}+$ allele and $\mathrm{H}-$ allele were found between the 2 groups in either male or female subjects.

Univariate analysis was performed to illustrate associations between environmental factors and HTG risks. The results indicated that educational level $(\leq 6$ years of education, $\mathrm{OR}=2.6,95 \% \mathrm{CI}: 1.3-5.1$ ), tribal background 
(Amis, OR=2.6, 95\% CI: 1.4-5.2), BMI $(\geq 25, \mathrm{OR}=1.9$, 95\% CI: 1.1-3.4), frequency of starchy food (except for rice) consumption ( $\geq 3$ times/week, OR $=2.0,95 \% \mathrm{CI}: 1.1-3.4)$, cigarette use (OR $=2.1,95 \%$ CI: $1.1-3.8)$, betel nut or quid chewing ( $\mathrm{OR}=2.4,95 \% \mathrm{CI}$ : $1.3-4.3)$ were positively associated with HTG risk. Age, gender, hypertension and alcohol consumption were not related to HTG risk in the univariate analysis. Upon adjustment for covariance (Table 4), education $\leq 6$ year $(\mathrm{OR}=3.71,95 \%$ CI: 1.24 8.13), Amis tribe ( $\mathrm{OR}=3.08,95 \%$ CI: $1.41-6.77)$, $\mathrm{BMI} \geq 25$ $(\mathrm{OR}=2.22,95 \%$ CI: 1.18-4.16), starchy food consumption $\geq 3$ times/week (OR $=1.89,95 \%$ CI: $1.00-3.59)$ and ApoCIII S2S2 (OR =3.35, 95\% CI: 1.10-10.19) were independently associated with HTG risk (Table 4).

The TG and ApoCIII concentrations among ApoCIII $\mathrm{S} 1 \mathrm{~S} 1, \mathrm{~S} 1 \mathrm{~S} 2, \mathrm{~S} 2 \mathrm{~S} 2$ genotypes are shown in Table 5. TG (p for trend $=0.017$ ) and ApoCIII ( $\mathrm{p}$ for trend $=0.007$ ) concentrations were increased in subjects with S1S1, S1S2 and S2S2 genotypes in a dose-responsive manner, although only individuals with S2S2 genotype had significantly higher TG and ApoCIII concentrations compared with the other 2 genotypes $(\mathrm{p}<0.05)$. This relation was also examined separately in the male and female groups. In the female group, concentrations of TG ( $p$ for trend $=0.044$ ) and ApoCIII ( $\mathrm{p}$ for trend $<0.001$ ) remained significantly associated with S1S1, S1S2 and S2S2 genotypes, but not in the male subjects $(\mathrm{p}>0.05)$.

\section{Discussion}

We report a significant association between ApoCIII SstI polymorphism and risks of HTG in female Taiwan aborigines. A marginal significance $(\mathrm{p}=0.078)$ between $\mathrm{HTG}$ and NTG for S2 distribution was found in all subjects. As further analyzed in the female participants, S2 allele frequency was significantly $(\mathrm{p}<0.04)$ higher in the HTG group than in NTG subjects. Taiwan aborigines are genetically different from Han Chinese, and one theory ${ }^{24,25}$ suggests that they are genetically related to Austronesians who migrated from South-East Asia and arrived 6,000-9,000 years ago in Taiwan; later, Austronesians reached central Polynesia in 200 BC and spread further out across the Pacific Ocean island groups, finally reaching Tahiti, then Hawaii and then New Zealand between 600-800 AD (though there was likely a later migration wave around 1,200 AD from the Society Islands to New Zealand), by that time having evolved to become proto-Polynesians in cultural, language and artifact specializations. Furthermore, recent mitochondrial DNA analysis supports the link between Taiwan aborigines and
Table 4 Multivariate Logistic Regression Analysis of the Effects of ApoCIII (Sst-I) Polymorphism and Environmental Factors on the Risks of HTG

\begin{tabular}{|c|c|c|c|}
\hline \multirow[b]{2}{*}{ Variable } & \multicolumn{2}{|c|}{ Classification } & \multirow[b]{2}{*}{$\begin{array}{l}\text { Odds ratio } \\
(95 \% C I)\end{array}$} \\
\hline & $\begin{array}{c}H T G \\
(n=90) \\
n\end{array}$ & $\begin{array}{c}N T G \\
(n=159) \\
n\end{array}$ & \\
\hline \multicolumn{4}{|l|}{ Education } \\
\hline$>6$ years & 13 & 49 & 1.0 \\
\hline$\leq 6$ years & 75 & 110 & $3.71(1.24-8.13)$ \\
\hline \multicolumn{4}{|l|}{ Tribe } \\
\hline Paiwan & 65 & 139 & 1.0 \\
\hline Amis & 25 & 20 & $3.08(1.41-6.77)$ \\
\hline \multicolumn{4}{|l|}{ Body mass index } \\
\hline$<25$ & 26 & 70 & 1.0 \\
\hline$\geq 25$ & 63 & 86 & $2.22(1.18-4.16)$ \\
\hline \multicolumn{4}{|l|}{ Starchy food intake } \\
\hline$<3$ times/week & 27 & 75 & 1.0 \\
\hline$\geq 3$ times $/$ week & 60 & 84 & $1.89(1.00-3.59)$ \\
\hline \multicolumn{4}{|l|}{ Cigarette use } \\
\hline No & 61 & 130 & 1.0 \\
\hline Yes & 28 & 29 & $1.41(0.67-2.98)$ \\
\hline \multicolumn{4}{|l|}{ Betel nut use } \\
\hline No & 19 & 62 & 1.0 \\
\hline Yes & 70 & 97 & $1.98(0.99-4.00)$ \\
\hline \multicolumn{4}{|l|}{ ApoCIII genotype } \\
\hline S1S1 & 42 & 85 & 1.0 \\
\hline S1S2 & 35 & 64 & $0.8(0.47-1.69)$ \\
\hline$S 2 S 2$ & 13 & 10 & $3.35(1.10-10.19)$ \\
\hline
\end{tabular}

Model was adjusted for age and sex: CI, confidence interval. Other abbreviations see in Tables 1,2.

If total number of subjects in each variable was not equal to 249 , there are missing values $(n=1-4)$.

Polynesians ${ }^{26}$ Associations between the rare S2 allele of ApoCIII and elevated TG have been reported in various different ethnic groups, including Japanese ${ }^{12}$ Asian Indians ${ }^{13}$ Arabs, ${ }^{14}$ Caucasians, ${ }^{15}$ and Chinese ${ }^{16}$ The present study found frequencies of the S2 allele in NTG and HTG subjects of 0.26 and 0.34 , respectively. The frequency of the $\mathrm{S} 2$ allele is in line with ranges reported for Chinese $(0.30$ $0.43),{ }^{16}$ Japanese $(0.25-0.48){ }^{12,27}$ and Indians $(0.31),{ }^{13}$ but is higher than those reported for Caucasians in whom the frequencies of the S2 allele have been $5-10 \%$ in most reports $(0.0-0.11) \cdot 14,15,28,29$ The clinical significance of possessing this allele has been demonstrated in some casecontrol studies that showed a 2- to 5-fold increase in frequency in patient groups with premature coronary heart and peripheral vascular disease compared with control groups ${ }^{30-33}$

Table 5 Relationship Between Concentrations of Plasma Triglycerides or Apolipoprotein CIII and Apolipoprotein CIII SstI Polymorphism

\begin{tabular}{lcccc}
\hline \hline & \multicolumn{3}{c}{ Mean \pm SD } & \multirow{2}{*}{ p for trend } \\
\cline { 2 - 3 } & S1S1 & S1S2 & S2S2 & \\
\hline Total $(n=249)$ & & & & \\
Triglycerides $(\mathrm{mg} / \mathrm{dl})$ & $137.8 \pm 97.5$ & $153.2 \pm 132.6$ & $219.2 \pm 252.5$ & 0.017 \\
Apolipoprotein CIII $(\mathrm{mg} / \mathrm{dl})$ & $8.2 \pm 3.6$ & $8.6 \pm 4.7$ & $11.5 \pm 4.7$ & 0.007 \\
Males $(n=77)$ & & & & 0.122 \\
Triglycerides $(\mathrm{mg} / \mathrm{dl})$ & $165.9 \pm 112.9$ & $182.9 \pm 167.0$ & $356.0 \pm 553.0$ & 0.323 \\
Apolipoprotein CIII $(\mathrm{mg} / \mathrm{dl})$ & $9.4 \pm 4.4$ & $10.3 \pm 6.3$ & $15 \pm 8.5$ & \\
Females $(n=172)$ & & & & \\
Triglycerides $(\mathrm{mg} / \mathrm{dl})$ & $123.4 \pm 86.0$ & $140.3 \pm 113.5$ & $190.4 \pm 148.2$ & 0.044 \\
Apolipoprotein CIII $(\mathrm{mg} / \mathrm{dl})$ & $7.72 \pm 3.1$ & $7.87 \pm 3.6$ & $11.2 \pm 4.5$ & $<0.001$ \\
\hline
\end{tabular}

Data are mean $\pm S D$ and $p<0.05$ considered statistically significant. Abbreviation see in Table 1. 
The biochemical basis for the association of the S2 allele with HTG has yet to be established. Similar to the finding of other studies, ${ }^{34-37}$ we also found a positive association between plasma levels of ApoCIII and genotypes carrying the $\mathrm{S} 2$ variant. The gene coding for ApoCIII is situated $2.6 \mathrm{kbp}$ from the 3' end of the ApoAI gene and $6.5 \mathrm{kbp}$ from the 5' end of the ApoAIV gene ${ }^{38}$ The SstI polymorphism, arising from a cytosine to guanosine substitution, is located in the 3' UTR of ApoCIII. Therefore, it is more likely that the S2 allele is not etiological, but is in linkage disequilibrium with other unknown causative mutations in ApoCIII or nearby genes involved in the metabolism of TG molecules. It has been suggested that certain haplotypes generated from Sst1 polymorphism of ApoCIII may predispose to HTG; 39 however, few of the studies carried out in Caucasians, ${ }^{40,41}$ Taiwanese, ${ }^{18}$ Japanese $^{42}$ and Arabs ${ }^{17}$ have not found any significant association between SstI polymorphism and HTG. It is speculated that the linkage disequilibrium between the polymorphic site and the causative mutation is weakened or absent in some populations ${ }^{37}$ It should be noted that some of the discrepancies reported in the literature could be related to gene/environmental interactions, such as those described for dietary variations. ${ }^{43}$

In this study, HTG subjects $(134.4 \mathrm{mg} / \mathrm{dl})$ also had significantly $(\mathrm{p}<0.01)$ higher fasting glucose concentrations than NTG subjects $(106.6 \mathrm{mg} / \mathrm{dl})$. Recently, Salas et al ${ }^{44}$ reported that subjects carrying the $\mathrm{S} 2$ variant of ApoCIII SstI polymorphism had an elevated insulin response to an oral glucose tolerance test when they consumed diets rich in saturated fat. The mechanism by which this polymorphism modulates insulin sensitivity is unknown. A possible explanation is that the $\mathrm{S} 2$ allele is in disequilibrium with 2 other polymorphisms, $-455 \mathrm{~T}>\mathrm{C}$ and $-482 \mathrm{C}>\mathrm{T}$, which occur within the insulin responsive element in the ApoCIII promoter region! ${ }^{4}$ ApoCIII expression is normally downregulated $40-50 \%$ by insulin. The presence of a rare allele of either variant $(-455 \mathrm{~T}>\mathrm{C}$ or $-482 \mathrm{C}>\mathrm{T})$ was proved sufficient to remove the ability of insulin to inhibit ApoCIII expression, 45 which subsequently leads to increased levels of ApoCIII as well as TGs in the blood. Further, it was previously reported that variation at the $\mathrm{C}-482 \mathrm{~T}$ determined the response to the oral glucose tolerance test (variant in the ApoCIII promoter), with carriers of the rare $\mathrm{T}-482$ having significantly elevated glucose and insulin concentrations 46 That finding demonstrates some of the interactions occurring between lipid and glucose metabolism and supports the possible involvement of ApoCIII in the development of impaired glucose metabolism.

In the multivariate-adjusted model, ApoCIII S2S2 (OR= 3.35, 95\% CI: 1.10-10.19) was positively associated with HTG risk, and a significant linear trend $(\mathrm{p}<0.05)$ of ApoCIII and TG concentrations for the S1S1, S1S2, S2S2 genotypes was also detected, further confirming the relationship between the rare S2 allele and risk of HTG (Table 5). As we further analyzed gender, the serum TG and ApoCIII concentrations remained significantly associated with S1S1, $\mathrm{S} 1 \mathrm{~S} 2$ and S2S2 genotypes in a dose-responsive manner ( $\mathrm{p}<$ $0.05)$ in the female subjects $(n=172)$, but not in the males. This finding agrees with the conclusions of other reports 47,48 that have shown an influence of gender on relationships between ApoCIII polymorphisms and plasma lipid variables. Espino-Montoro et $\mathrm{al}^{47}$ reported an interaction between gender and ApoCIII SstI polymorphism in essential hypertensive patients. Significantly greater concentrations of plasma TG, C, and fasting plasma glucose were observed predominantly in female subjects carrying the rare S2 allele. Dallongeville et $\mathrm{al}^{48}$ demonstrated that serum TG and APOB concentrations were higher in women bearing the rare allele of SstI than in those with the most common allele, but not in men. These observations, as well as the current results, suggest a gender-related impact of ApoCIII SstI polymorphism on lipid-related variables. We postulate that sexual hormones may influence the production or catabolic rates of apolipoproteins and lipoproteins, which may in turn influence the potential role of ApoCIII on lipid metabolism. Alternatively, differences in lifestyle or diet between men and women may also exercise some influence.

Formation of HTG is determined by a complex interaction between genetic and environmental factors. In the current study, besides ApoCIII SstI polymorphism, several environmental factors, such as socioeconomic background and diet, were also investigated. Our multivariate-adjusted model demonstrated that education level ( $\leq 6$ years of education, $\mathrm{OR}=3.71,95 \% \mathrm{CI}$ : $1.24-8.13)$, tribal background (Amis tribe, $\mathrm{OR}=3.08,95 \% \mathrm{CI}: 1.41-6.77)$, BMI $(\geq 25$, $\mathrm{OR}=2.22$, 95\% CI: $1.18-4.16)$, starchy food consumption ( $\geq 3$ times/week, OR $=1.89$, 95\% CI: 1.00-3.59) were independently related to risk of HTG. Subjects receiving education $\leq 6$ years had a greater risk of $\mathrm{HTG}(\mathrm{OR}=3.71,95 \% \mathrm{CI}$ : 1.24-8.13) than those with more than 6 years of education. A similar influence of education level on blood lipid status has been documented previously by Dennis et $\mathrm{al}^{49}$ who reported that less educated men had higher blood pressure, higher HDL-C and, furthermore, in multivariate-adjusted logistic modeling, the relative risk for coronary heart diseases of the least-educated men compared with the mosteducated men was 1.9. In the current study, subjects with BMI $\geq 25$ were related to HTG risk $(p<0.05)$, which is consistent with other reports $5^{5}$ Further, HTG is one of the clinical parameters of metabolic syndrome. Zhang et $\mathrm{al}^{51}$ suggested that clustering of metabolic syndrome not only occurs more prevalently in persons with $\mathrm{BMI} \geq 25$, but also in normal-weight persons with large weight fluctuation. In addition, hypoadiponectinemia is closely associated with the clinical phenotype for metabolic syndrome, so measuring the plasma concentration of adiponectin may be a useful tool for managing metabolic syndrome52 Among dietary factors, diets high in fat and carbohydrates have been shown to elevate blood TG ${ }^{53}$ We found that consumption of starchy food $\geq 3$ times/week had a greater risk of HTG compared with $<3$ times/week. Excessive consumption of sugar and sweets is likely to contribute to a high frequency of HTG ${ }^{54}$ However, it has been suggested that the classification of carbohydrates into simple and complex carbohydrates may not be the most helpful predictor of their metabolic properties: ${ }^{3}$ Recently, it has been suggested that impaired dietary antioxidant status is related to presence of various coronary risk factors, including HTG and hypo-HDL55 Thus, further study is needed to investigate the relationships among various antioxidant-related dietary factors and the risk of HTG.

In the current study, we did not find significant associations between LPL-HindIII polymorphisms and HTG. The frequency of the $\mathrm{H}+$ allele of the LPL-HindIII polymorphism was 0.16 and 0.21 in the HTG and NTG subjects, respectively; there were no differences between the 2 groups. The frequency for $\mathrm{H}-$ is lower than that reported in Caucasians ${ }^{56,57}$ and Hispanics ${ }^{58}$ and is in the range of those found for Chinese ${ }^{16}$ Larger sample sizes may be needed to further confirm the relationship between the rare $\mathrm{H}$ - allele 
and the risk of HTG.

In conclusion, we found a higher prevalence of the rare S2 allele of molecular variants of ApoCIII SstI polymorphism in subjects with HTG among Taiwan aboriginal females. Distribution of the S2 allele in the study population was in line with that for Asians, such as Chinese, Japanese and Indians. In a multivariate-adjusted logistic regression model, the ApoCIII S2S2 genotype was independently $(\mathrm{OR}=3.35)$ associated with the risk of $\mathrm{HTG}$, and the plasma ApoCIII and TG concentrations were increased $(\mathrm{p}<0.01)$ accordingly among the ApoCIII S1S1, S1S2 and S2S2 genotypes. Besides the ApoCIII S2S2 genotype, environmental factors (ie, education $\leq 6$ year $(\mathrm{OR}=3.71)$, Amis tribe $(\mathrm{OR}=3.08)$, BMI $\geq 25(\mathrm{OR}=2.22)$, starchy food consumption $\geq 3$ times/week and $(\mathrm{OR}=1.89))$ were also found independently $(\mathrm{p}<0.05)$ related to HTG risk. It appears that both genetic and environmental factors are associated with the phenotype of HTG. Further studies are warranted to examine interactions of ApoCIII polymorphism with other genes related to HTG, as well as with environmental factors.

\section{Acknowledgment}

This work is supported by the National Science Council, Taiwan (NSC91-2320-B-037-036).

\section{References}

1. Assmann G, Cullen P, Schulte H. The Munster Heart Study (PROCAM): Results of follow-up at 8 years. Eur Heart J 1998; 19: A2-A11.

2. Austin MA, Hokanson JE, Edwards KL. Hypertriglyceridemia as a cardiovascular risk factor. Am J Cardiol 1998; 81(4A): 7B -12B

3. National Cholesterol Education Program Expert Panel. National Institutes of Health: Third Report of the National Cholesterol Education Program Expert Panel on Detection, Evaluation, and Tretament of High Blood Cholesterol in Adults (Adult Treatment Panel III). Bethesda, MD: NIH; 2002. NIH Publication $10001-3670$.

4. Breslow JL. Mouse models of atherosclerosis. Science 1996; 27: $685-688$.

5. Department of Health, Executive Yuan, ROC. Nutrition and health Survey in Taiwan, NAHSIT, 1993-1996. Taipei, Republic of China, 1998.

6. Department of Health, Executive Yuan, ROC. Date of creation: December, 2002; Date of viewing: June, 2006.

7. Ko Y-C, Liu B-H, Hsieh S-F. Issues on aboriginal health in Taiwan. Kaohsiung J Med Sci 1994; 10: 337-351.

8. Department of Health, Executive Yuan, ROC. Health and Vital statistics Vol 2: Vital statistics. Taipei, Republic of China, 2004.

9. Bruns GA, Karathanasis SK, Breslow JL. Human apolipoprotein AI-C-III gene complex is located on chromosome 11. Arteriosclerosis 1984; 4: 97-102.

10. Wang CS, McConathy WJ, Kloer HU, Alaupovic P. Modulation of lipoprotein lipase activity by apolipoproteins: Effect of apolipoprotein C-III. J Clin Invest 1985; 75: 384-390.

11. Schonfeld G, George PK, Miller J, Reilly P, Witztum J. Apolipoprotein C-II and C-III levels in hyperlipoproteinemia. Metabolism 1979; 28: $1001-1010$

12. Bai H, Saku K, Liu R, Imamura M, Arakawa K. Association between coronary heart disease and the apolipoprotein A-I/C-III/A-IV complex in a Japanese population. Hum Genet 1995; 95: 102-104.

13. Chhabra S, Narang R, Krishnan LR, Vasisht S, Agarwal DP, Srivastava LM, et al. Apolipoprotein CIII SstI polymorphism and triglyceride levels in Asian Indians. BMC Genet 2002; 3: 9.

14. Dammerman M, Sandkuijl LA, Halaas JL, Chung W, Breslow JL. An apolipoprotein CIII haplotype protective against hypertriglyceridemia is specified by promoter and 3' untranslated region polymorphisms. Proc Natl Acad Sci USA 1993; 90: 4562-4566.

15. Tybjaerg-Hansen A, Nordestgaard BG, Gerdes LU, Faergeman O, Humphries SE. Genetic markers in the apo AI-CIII-AIV gene cluster for combined hyperlipidemia, hypertriglyceridemia, and predisposition to atherosclerosis. Atherosclerosis 1993; 100: 157-169.

16. Ko YL, Ko YS, Wu SM, Teng MS, Chen FR, Hsu TS, et al. Interaction between obesity and genetic polymorphisms in the apolipoprotein CIII gene and lipoprotein lipase gene on the risk of hypertriglyc- eridemia in Chinese. Hum Genet 1997; 100: 327-333.

17. Johansen K, Dunn B, Tan JC, Kwaasi AA, Skotnicki A, Skotnicki M. Coronary artery disease and apolipoprotein A-I/C-III gene polymorphism: A study of Saudi Arabians. Clin Genet 1991; 39: 1-5.

18. Wu JH, Kao JT, Wen MS, Lo SK. DNA polymorphisms at the apolipoprotein A1-CIII loci in Taiwanese: Correlation of plasma APOCIII with triglyceride level and body mass index. J Formos Med Assoc 2000; 99: 367-374.

19. Sparkes RS, Zollman S, Klisak I, Kirchgessner TG, Komaromy MC, Mohandas T, et al. Human genes involved in lipolysis of plasma lipoproteins: Mapping of loci for lipoprotein lipase to 8p22 and hepatic lipase to $15 \mathrm{q} 21$. Genomics $1987 ; \mathbf{1}$ : 138-144.

20. Razzaghi H, Aston CE, Hamman RF, Kamboh MI. Genetic screening of the lipoprotein lipase gene for mutations associated with high triglyceride/low HDL-cholesterol levels. Hum Genet 2000; 107: 257-267.

21. Peacock RE, Hamsten A, Nilsson-Ehle P, Humphries SE. Associations between lipoprotein lipase gene polymorphisms and plasma correlations of lipids, lipoproteins and lipase activities in young myocardial infarction survivors and age-matched healthy individuals from Sweden. Atherosclerosis 1992; 97: 171-185.

22. Anderson JL, King GJ, Bair TL, Elmer SP, Muhlestein JB, Habashi $\mathrm{J}$, et al. Association of lipoprotein lipase gene polymorphisms with coronary artery disease. J Am Coll Cardiol 1999; 33: 1013-1020.

23. Department of Population. Consensus 1990: Census report of the Republic of China in Taiwan. Taipei, ROC, 1992.

24. Bellwood P. The Austronesian dispersal and the origin of languages. Sci Am 1991; 265: 70-75.

25. Blust R. The Austronesian homeland: A linguistic perspective. Asian Perspect 1988; 26: 45-67.

26. Melton T, Peterson R, Redd AJ, Saha N, Sofro AS, Martinson J, et al. Polynesian genetic affinities with Southeast Asian populations as identified by mtDNA analysis. Am J Hum Genet 1995; 57: 403-414.

27. Zeng Q, Dammerman M, Takada Y, Matsunaga A, Breslow JL, Sasaki J. An apolipoprotein CIII marker associated with hypertriglyceridemia in Caucasians also confers increased risk in a west Japanese population. Hum Genet 1995; 95: 371-375.

28. Russo GT, Meigs JB, Cupples LA, Demissie S, Otvos JD, Wilson $\mathrm{PW}$, et al. Association of the Sst-I polymorphism at the APOCIII gene locus with variations in lipid levels, lipoprotein subclass profiles and coronary heart disease risk: The Framingham offspring study. Atherosclerosis 2001; 158: 173-181.

29. Rees A, Shoulders CC, Stocks J, Galton DJ, Baralle FE. DNA polymorphism adjacent to human apoprotein A-1 gene: Relation to hypertriglyceridaemia. Lancet 1983; 1: 444-446.

30. Ferns GA, Stocks J, Ritchie C, Galton DJ. Genetic polymorphisms of apolipoprotein C-III and insulin in survivors of myocardial infarction. Lancet 1985; 2: 300-303.

31. O'Connor G, Stocks J, Lumley J, Galton DJ. A DNA polymorphism of the apolipoprotein C-III gene in extracoronary atherosclerosis. Clin Sci (Lond) 1988; 74: 289-292.

32. Price WH, Morris SW, Kitchin AH, Wenham PR, Burgon PR, Donald PM. DNA restriction fragment length polymorphisms as markers of familial coronary heart disease. Lancet 1989; 1: 1407-1411.

33. Rees A, Stocks J, Williams LG, Caplin JL, Jowett NI, Camm AJ, et al. DNA polymorphisms in the apolipoprotein C-III and insulin genes and atherosclerosis. Atherosclerosis 1985; 58: 269-275.

34. Dallinga-Thie GM, Bu XD, van Linde-Sibenius Trip M, Rotter JI, Lusis AJ, de Bruin TW. Apolipoprotein A-I/C-III/A-IV gene cluster in familial combined hyperlipidemia: Effects on LDL-cholesterol and apolipoproteins B and C-III. J Lipid Res 1996; 37: 136-147.

35. Dallinga-Thie GM, van Linde-Sibenius Trip M, Rotter JI, Cantor $\mathrm{RM}, \mathrm{Bu} \mathrm{X}$, Lusis AJ, et al. Complex genetic contribution of the Apo AI-CIII-AIV gene cluster to familial combined hyperlipidemia: Identification of different susceptibility haplotypes. J Clin Invest 1997; 99: $953-961$.

36. Shoulders CC, Harry PJ, Lagrost L, White SE, Shah NF, North JD, et al. Variation at the apo AI/CIII/AIV gene complex is associated with elevated plasma levels of apo CIII. Atherosclerosis 1991; 87: 239_ 247.

37. Shoulders CC, Grantham TT, North JD, Gaspardone A, Tomai F, de Fazio A, et al. Hypertriglyceridemia and the apolipoprotein CIII gene locus: Lack of association with the variant insulin response element in Italian school children. Hum Genet 1996; 98: 557-566.

38. Karathanasis SK. Apolipoprotein multigene family: Tandem organization of human apolipoprotein AI, CIII, and AIV genes. Proc Natl Acad Sci USA 1985; 82: 6374-6378.

39. Hong SH, Park WH, Lee CC, Song JH, Kim JQ. Association between genetic variations of apo AI-CIII-AIV cluster gene and hypertriglyceridemic subjects. Clin Chem 1997; 43: 13-17. 
40. Sidoli A, Giudici G, Soria M, Vergani C. Restriction-fragmentlength polymorphisms in the A-I-C-III gene complex occurring in a family with hypoalphalipoproteinemia. Atherosclerosis 1986; 62: $81-87$.

41. Marcil M, Boucher B, Gagne E, Davignon J, Hayden M, Genest J Jr. Lack of association of the apolipoprotein A-I-C-III-A-IV gene XmnI and SstI polymorphisms and of the lipoprotein lipase gene mutations in familial combined hyperlipoproteinemia in French Canadian subjects. J Lipid Res 1996; 37: 309-319.

42. Rees A, Stocks J, Paul H, Ohuchi Y, Galton D. Haplotypes identified by DNA polymorphisms at the apolipoprotein A-1 and C-III loci and hypertriglyceridaemia: A study in a Japanese population. Hum Genet 1986; 72: $168-171$.

43. Ordovas JM, Schaefer EJ. Genes, variation of cholesterol and fat intake and serum lipids. Curr Opin Lipidol 1999; 10: 15-22.

44. Salas J, Jansen S, Lopez-Miranda J, Ordovas JM, Castro P, Marin C, et al. The SstI polymorphism of the apolipoprotein C-III gene determines the insulin response to an oral-glucose-tolerance test after consumption of a diet rich in saturated fats. Am J Clin Nutr 1998; 68: 396-401.

45. Li WW, Dammerman MM, Smith JD, Metzger S, Breslow JL, Leff T. Common genetic variation in the promoter of the human apo CIII gene abolishes regulation by insulin and may contribute to hypertriglyceridemia. J Clin Inves 1995; 96: 2601-2605.

46. Waterworth DM, Ribalta J, Nicaud V, Dallongeville J, Humphries SE, Talmud P. ApoCIII gene variants modulate postprandial response to both glucose and fat tolerance tests. Circulation 1999; 99: $1872-$ 1877.

47. Espino-Montoro A, Barrios-Artillo M, Lopez-Chozas JM, Cayuela A, Stiefel P, Villar J. Influence of polymorphism (RFLP-sstI) at the apolipoprotein C-III gene locus on the lipoprotein metabolism and insulin resistance in essential hypertensive patients-Interaction between gender and genetic polymorphism. Nutr Metab Cardiovasc Dis 2003; 13: 194-201.

48. Dallongeville J, Meirhaeghe A, Cottel D, Fruchart JC, Amouyel P, Helbecque N. Gender related association between genetic variations of APOC-III gene and lipid and lipoprotein variables in northern
France. Atherosclerosis 2000; 150: 149-157.

49. Dennis BH, Zhukovsky GS, Shestov DB, Davis CE, Deev AD, Kim

$\mathrm{H}$, et al. The association of education with coronary heart disease mortality in the USSR Lipid Research Clinics Study. Int J Epidemiol 1993; 22: 420-427.

50. Thomas GN, Ho SY, Lam KS, Janus ED, HedLey AJ, Lam TH, Hong Kong Cardiovascular Risk Factor Prevalence Study Steering Committee. Impact of obesity and body fat distribution on cardiovascular risk factors in Hong Kong Chinese. Obes Res 2004; 12: $1805-$ 1813.

51. Zhang H, Tamakoshi K, Yatsuya H, Murata C, Wada K, Otsuka R, et al. Long-term body weight fluctuation is associated with metabolic syndrome independent of current body mass index among Japanese men. Circ J 2005; 69: 13-18.

52. Ryo M, Nakamura T, Kihara S, Kumada M, Shibazaki S, Takahashi $\mathrm{M}$, et al. Adiponectin as a biomarker of the metabolic syndrome. Circ J 2004; 68: 975-981.

53. Fried SK, Rao SP. Sugars, hypertriglyceridemia, and cardiovascular disease. Am J Clin Nutr 2003; 78: 873S-880S.

54. Kamel BS, Martenez OB. Food habits and nutrient intake in Kuwaiti in males and females. Ecol Food Nutr 1985; 15: 261-272.

55. Miwa K, Okinaga S, Fujita M. Low serum alpha-tocopherol concentrations in subjects with various coronary risk factors. Circ J 2004; 68: $542-546$.

56. Humphries SE, Nicaud V, Margalef J, Tiret L, Talmud PJ. Lipoprotein lipase gene variation is associated with a paternal history of premature coronary artery disease and fasting and postprandial plasma triglycerides: The European Atherosclerosis Research Study (EARS). Arterioscler Thromb Vasc Biol 1998; 18: 526-534.

57. Chamberlain JC, Thorn JA, Oka K, Galton DJ, Stocks J. DNA polymorphisms at the lipoprotein lipase gene: Associations in normal and hypertriglyceridaemic subjects. Atherosclerosis 1989; 79: 85-91.

58. Corella D, Guillen M, Saiz C, Portoles O, Sabater A, Folch J, et al. Associations of LPL and APOCIII gene polymorphisms on plasma lipids in a Mediterranean population: Interaction with tobacco smoking and the APOE locus. J Lipid Res 2002; 43: 416-427. 